\title{
Biological effects of encapsulated insulin on transfected Chinese hamster ovary cells
}

\author{
M. Roques, G. Crémel, D. Aunis, P. Hubert \\ INSERM U. 338, Strasbourg, France
}

Summary Oral administration of insulin incorporated into the wall of isobutylcyanoacrylate nanocapsule to diabetic rats induces a long-lasting normalization of their fasting glycaemia. In this study, we examined the biological action of encapsulated insulin on DNA and glycogen syntheses in Chinese hamster ovary cells transfected with the human insulin receptor gene. In the $10^{-11} \mathrm{~mol} / 1-10^{-9} \mathrm{~mol} / 1$ concentration range, encapsulated insulin elicited responses comparable to those induced by native insulin: at $10^{-9} \mathrm{~mol} / 1$, the rates of glycogen and DNA synthesis were enhanced by factors 3 and 2.5, respectively. Encapsulated insulin at $10^{-7} \mathrm{~mol} / \mathrm{l}$ evoked receptor desensitization although it did not induce receptor down-regulation and did not alter receptor recycling for up to $6 \mathrm{~h}$. Chloroquine decreased the action of native insulin on glycogen synthesis, but did not affect the dose-response characteristics of encapsulated insulin. Acid- washing of the cells after $1 \mathrm{~h}$ of stimulation decreased maximal insulin responsiveness and provoked a dose response curve for encapsulated insulin similar to that of the native hormone. Direct measurement of effective insulin binding activity showed that encapsulated insulin (at $10^{-8}$ and $10^{-7} \mathrm{~mol} / \mathrm{l}$ ) was withdrawn from the incubation medium 5-8 times less efficiently than native insulin. These data are in agreement with previous results showing that the polymeric wall protects encapsulated insulin from degradation. Persistence of intact encapsulated insulin inside and outside the cell may result in modifying signalling events and thus be responsible for the observed cellular desensitization.[Diabetologia (1995) 38: 180-186]

Key words Insulin pharmacology, insulin metabolism, oral administration, dose-response relationship, cultured cells.
Because patients have difficulty in accepting daily subcutaneous injections of insulin, many studies have been performed to find new types of insulin therapies e.g. bioartificial pancreas $[1,2]$, nasal [3] or rectal administration [4]. Among the new strategies in diabetes treatment, oral administration would appear to be the most convenient for patients. However, the success of such a strategy depends on its ca-

Received: 23 May 1994 and in revised form: 13 September 1994

Corresponding author: Dr. P. Hubert, INSERM U. 338, 5 rue Blaise Pascal, F-67000 Strasbourg, France

Abbreviations: IR-CHO, Chinese hamster ovary cells transfected with the human insulin receptor gene; BSA, bovine serum albumin; HEPES, 4-(2-hydroxyethyl)-1-piperazine ethanesulfonic acid; PBS, phosphate buffered saline. pacity to protect insulin against proteolytic degradation and on the ability of the peptide to pass through the intestinal mucosa. These conditions have been fulfilled by associating insulin to nanocapsules of isobutylcyanoacrylate $[5,6]$, a polymer which is biocompatible and biodegradable $[7,8]$. These spherical vesicles are constituted by a polymeric wall surrounding an inner lipidic cavity. It has previously been shown that, after intragastric gavage with encapsulated insulin, streptozotocin-induced diabetic rats have their fasting glycaemia normalized for a period of 1 to 3 weeks in a dose-dependent fashion [9]. In addition, encapsulated insulin has a modified tissue distribution and a delayed urinary excretion [6].

More recently, we have demonstrated that the interaction of encapsulated insulin with insulin receptors in vitro is similar to that of native insulin with re- 
gard to binding, negative co-operativity and autophosphorylation [10]. These data suggest that the binding site of the hormone is directly accessible to the receptor. Rates of internalization were very similar for both forms of insulin. However, HPLC analysis of native or encapsulated ${ }^{125}$ I-insulin after internalization for $3 \mathrm{~h}$ showed that encapsulated insulin is still protected against proteolytic degradation inside the cell. Assuming that this property could result in biological actions specific to encapsulated insulin we examined the effects of insulin on the rates of glycogen and DNA synthesis in Chinese hamster ovary (CHO) cells transfected with the human insulin receptor gene. This approach may help to further understand the action of encapsulated insulin in vivo.

\section{Materials and methods}

Preparation of nanocapsules. Nanocapsules were prepared by interfacial emulsion polymerization of isobutylcyanoacrylate as previously described [9]. The final suspension of nanocapsules contained $0.4 \mathrm{mg}$ insulin $/ 10 \mathrm{mg}$ polymer $/ \mathrm{ml}\left(6.7 \times 10^{-5}\right.$ $\mathrm{mol} / \mathrm{l}$ ) and the rate of encapsulation was greater than $98 \%$. For control experiments, empty nanocapsules prepared using the same procedure but in the absence of insulin were coated with bovine serum albumin (BSA). Alternatively, nanocapsules were prepared as above and inactivated by disulfide bond-reduction of insulin [11].

Cell culture. Chinese hamster ovary cells stably transfected with insulin receptor cDNA containing the alternatively spliced segment that corresponds to exon 11 (IR-CHO) were used (gift from E. Clauser, Paris, France). These cells possess about $5 \times 10^{5}$ insulin receptors per cell, as compared to about $5 \times 10^{3}$ sites per cell for the untransfected CHO cells [12], and were grown in Ham's F12 medium supplemented with $10 \%$ fetal calf serum (Gibco, Cergy-Pontoise, France) and with the neomycin analogue $\mathrm{G} 418(0.75 \mathrm{mg} / \mathrm{ml})$ (Gibco).

Glycogen synthesis. $\left[{ }^{14} \mathrm{C}\right]$ Glucose (Amersham, Aylesbury, UK, $270 \mathrm{mCi} / \mathrm{mmol}$ ) incorporation into glycogen was performed as previously described [13]: confluent IR-CHO cells were incubated with different concentrations of native or encapsulated insulin for $1 \mathrm{~h}$ in phosphate buffered saline (PBS) containing $0.1 \% \mathrm{BSA}, \mathrm{CaCl}_{2} 0.1 \mathrm{~g} / 1$ and $\mathrm{MgCl}_{2} 0.1 \mathrm{~g} / \mathrm{l}$. $\left[{ }^{14} \mathrm{C}\right]$ Glucose was then added for $3 \mathrm{~h}$. After incubation, cells were washed three times with ice-cold PBS, lysed with $30 \% \mathrm{KOH}$ and transferred to glass tubes. The tubes were boiled for $30 \mathrm{~min}$ and glycogen was precipitated overnight at $-20^{\circ} \mathrm{C}$ with $2 \mathrm{mg}$ of carrier glycogen and 2 volumes of ethanol. After centrifugation at $3,000 \mathrm{~g}$ for $20 \mathrm{~min}$, the precipitate was dissolved in water and radioactivity was counted.

Glycogen synthesis was also determined by the same procedure in the presence of chloroquine $(0.2 \mathrm{mmol} / \mathrm{l})$. In another series of experiments, native or encapsulated insulin was removed from the plasma membrane after 1 hour by acid-washing with $\mathrm{CH}_{3} \mathrm{COOH}(0.2 \mathrm{~mol} / \mathrm{l})-\mathrm{NaCl}(0.5 \mathrm{~mol} / \mathrm{l})(\mathrm{pH}=6)$ before the addition of $\left[{ }^{14} \mathrm{C}\right]$ glucose.

$D N A$ synthesis. [ $\left.{ }^{3} \mathrm{H}\right]$ Thymidine (Amersham, $130 \mathrm{Ci} / \mathrm{mmol}$ ) incorporation into DNA was performed as described by Leconte et al. [13]. Cells were grown in 12-well plates until they reached $2 / 3$ confluence and were depleted for $48 \mathrm{~h}$ in serumfree F12 medium containing $0.1 \% \mathrm{BSA}$ and $10 \mathrm{mmol} / \mathrm{l} \mathrm{HE}$ PES ( $\mathrm{pH}=7.4)$. Native or encapsulated insulin was added for $16 \mathrm{~h}$ before a 45 -min pulse with $\left[{ }^{3} \mathrm{H}\right]$ thymidine. Cells were washed twice with $5 \%$ trichloroacetic acid (TCA), solubilized in $1 \mathrm{~N} \mathrm{NaOH}$ and neutralized with $12 \mathrm{~N} \mathrm{HCl}$.

Down-regulation and recycling of the receptor. Confluent monolayers in 12-well dishes were deprived of serum for $24 \mathrm{~h}$ and then incubated with native or encapsulated insulin $\left(10^{-7}\right.$ $\mathrm{mol} / \mathrm{l}$ ) in Krebs-Ringer-HEPES ( $25 \mathrm{mmol} / \mathrm{l}$ ) buffer containing $1 \%$ BSA, for various times at $37^{\circ} \mathrm{C}$. For the 20 -h stimulation period, incubations were performed in serum-free Ham's F12 medium. Incubations were stopped by washing in ice-cold Krebs-Ringer-HEPES buffer $(\mathrm{pH}=7.4)$ followed by washing once with $\mathrm{NaCl}(0.5 \mathrm{~mol} / 1)-\mathrm{CH}_{3} \mathrm{COOH}(0.2 \mathrm{~mol} / 1)(\mathrm{pH}=4.5)$ for $5 \mathrm{~min}$ at $4{ }^{\circ} \mathrm{C}$ and twice with $\mathrm{PBS}(\mathrm{pH}=7.4)$. ${ }^{125} \mathrm{I}$-labelled insulin binding was then measured directly (down-regulation) or after a 30 -min incubation at $37^{\circ} \mathrm{C}$ in the Krebs-Ringer-HEPES buffer (recycling). Binding was performed overnight with ${ }^{125} \mathrm{I}$ (A14)-monoiodinated insulin (Amersham) (30-40,000 $\mathrm{cpm} /$ well, final concentration $\left.10^{-10} \mathrm{~mol} / \mathrm{l}\right)$. Non-specific binding was determined in parallel in the presence of insulin $10^{-6}$ $\mathrm{mol} / \mathrm{l}$. Cells were then harvested in $\mathrm{NaOH} 0.2 \mathrm{~N}$ and radioactivity was counted. The results are expressed as the percentage of ${ }^{125} \mathrm{I}$-labelled insulin binding in control cells.

Binding assay after incubation with cultured cells. Confluent IR-CHO cells in 12-well dishes were incubated with native or encapsulated insulin $\left(10^{-7}\right.$ and $\left.10^{-8} \mathrm{~mol} / \mathrm{l}\right)$, or empty nanocapsules at equivalent concentrations, in a Krebs-Ringer buffer $(\mathrm{pH}=7.4)$. After various incubation periods, an aliquot of the incubation medium was tested for its ability to displace binding of ${ }^{125} \mathrm{I}$-insulin to partially purified insulin receptors. Brief$1 y$, insulin receptors were solubilized from IR-CHO cells and purified by wheat germ agglutinin-agarose (E.Y labs., San Mateo, Calif., USA) chromatography [14]. Solubilized receptors were incubated overnight at $4^{\circ} \mathrm{C}$ with ${ }^{125} \mathrm{I}$-insulin $(20,000 \mathrm{cpm} /$ assay) and aliquots of incubation medium in $50 \mathrm{mmol} / \mathrm{l} \mathrm{HE}$ PES $(\mathrm{pH}=7.6), 150 \mathrm{mmol} / \mathrm{l} \mathrm{NaCl}$ containing $0.5 \% \mathrm{BSA}$ and $0.05 \%$ Triton X100. Bound insulin was measured after precipitation with polyethylene glycol [14]. Concentrations of active extracellular hormone were deduced from control competition curves performed in parallel.

\section{Results}

Effect of encapsulated insulin on glycogen and DNA synthesis. Under our experimental conditions, native and encapsulated insulin elicited identical stimulatory effects on rates of glycogen and DNA synthesis in the $10^{-11} \mathrm{~mol} / \mathrm{l}$ to $10^{-9} \mathrm{~mol} / \mathrm{l}$ concentration range. Glycogen and DNA synthesis were enhanced by factors 3 and 2.5 respectively at $10^{-9} \mathrm{~mol} / 1$ (Fig. 1 ). At the concentration of $10^{-8} \mathrm{~mol} / \mathrm{l}$, native insulin increased both glycogen and DNA synthesis 4.5-fold, whereas the effect of encapsulated insulin appeared to level off. $\mathrm{Na}$ tive insulin $10^{-7} \mathrm{~mol} / \mathrm{l}$ induced a maximal 5.5 -fold and five fold increase in glycogen and DNA synthesis respectively. In contrast, $10^{-7} \mathrm{~mol} / 1$ encapsulated insulin had no stimulatory effect on glycogen synthesis, and induced only a 1.8-fold increase in incorporation of $\left[{ }^{3} \mathrm{H}\right]$ thymidine. Such biphasic dose-response 


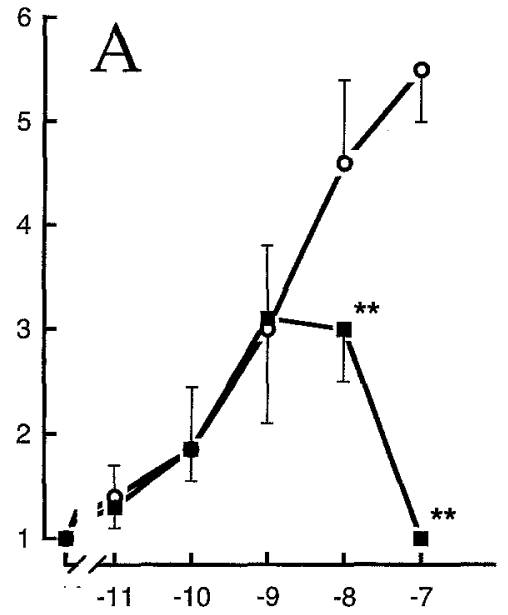

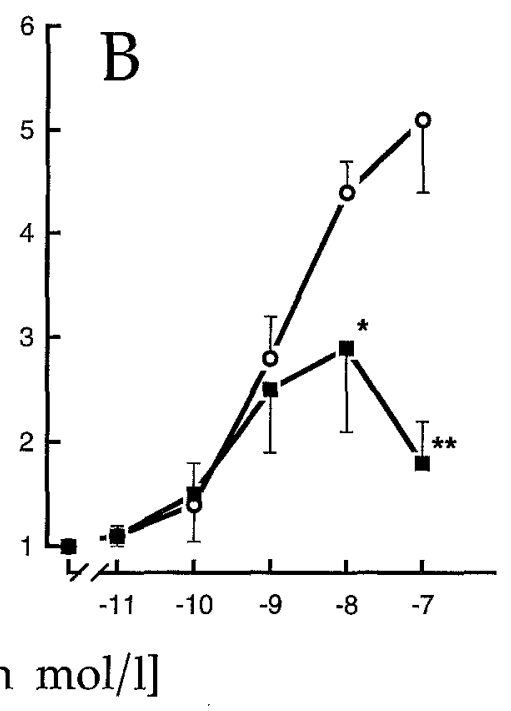

Fig. 1. (A, B) Effects of native $(O)$ and encapsulated ( $\mathbf{(})$ insulin effects on $(\mathbf{A})$ glycogen synthesis and (B) cellular growth of IR-CHO cells. (A) IR-CHO cells were stimulated for $4 \mathrm{~h}$ and the incorporation of $\left[{ }^{14} \mathrm{C}\right]$ glucose $(5 \mathrm{mmol} / \mathrm{l}, 2 \mu \mathrm{Ci} /$ well $)$ into glycogen was measured during the last $3 \mathrm{~h}$ of stimulation. All points were determined in triplicate and represent the means \pm $\mathrm{SD}$ of three experiments on three different cultures. (B) IR-CHO cells were stimulated with native or encapsulated insulin for $16 \mathrm{~h}$. Incorporation of $\left[{ }^{3} \mathrm{H}\right]$ thymidine $(0.5 \mu \mathrm{Ci} /$ well $)$ was performed during the last $45 \mathrm{~min}$ of stimulation. All points were determined in triplicate and represent means \pm SD of five experiments on five different cultures. Results are expressed as factors of stimulation compared to nontreated cells. Differences between native and encapsulated insulin ${ }^{*} p<0.05$;

${ }^{* *} p<0.01$ (unpaired Student's $t$-test) curves for encapsulated insulin are atypical. Their main feature is a decrease of hormone responsiveness at the higher doses, which is already apparent after a 4-h stimulation for glycogen synthesis.

This decreased responsiveness to encapsulated insulin was not related to toxic effects of the polymer; light microscopy showed no morphological cellular alterations, and cell counting revealed no apparent cell loss. In addition, the use of empty nanocapsules coated with exogenous BSA or prepared with reduced insulin did not change the basal incorporation of radiolabelled precursors $(920 \pm 180 \mathrm{cpm}$ in the absence compared to $930 \pm 175 \mathrm{cpm}$ in the presence of the polymer for incorporation of $\left[{ }^{14} \mathrm{C}\right]$ glucose; and $470 \pm 155 \mathrm{cpm}$ in the absence compared to $480 \pm 95$ $\mathrm{cpm}$ in the presence of the polymer for incorporation of $\left[{ }^{3} \mathrm{H}\right]$ thymidine). Furthermore, co-incubation of empty BSA-coated nanocapsules with native insulin did not alter the dose response curve for glycogen synthesis (data not shown).

Down-regulation and recycling of the receptor. The decreased response of IR-CHO cells at higher con- centrations of encapsulated insulin may be due to alteration in intracellular routing of the receptor after internalization. To test this possibility, receptor internalization and down-regulation were measured in IR-CHO cells. Native or encapsulated insulin did not induce down-regulation under our conditions (Table 1) after $6 \mathrm{~h}$ incubation. Very little if any receptor recycling occurred with both native and encapsulated insulin which appears to be a characteristic of insulin receptors encoded by the cDNA containing exon 11 [15]. After $20 \mathrm{~h}$ of incubation in the presence of encapsulated insulin, although the number of surface receptors was difficult to assess precisely because of high variability between experiments, no significant difference was found between native and encapsulated insulin.

Glycogen synthesis in the presence of chloroquine. We have previously shown that encapsulated ${ }^{125} \mathrm{I}$-insulin is largely intact $(85 \%$ as compared to $25 \%$ for native insulin) after $3 \mathrm{~h}$ internalization in IR-CHO cells [10]. The biphasic effect of encapsulated insulin may thus be related to differences in intracellular degradation.

Table 1. Down-regulation and recycling of the receptors in IR-CHO cells in the presence of native or encapsulated insulin

\begin{tabular}{lllll} 
& Insulin & & \multicolumn{2}{l}{ Encapsulated insulin } \\
\cline { 2 - 5 } & $\begin{array}{llll}\text { after } \\
\text { internalization }\end{array}$ & $\begin{array}{l}\text { after } \\
\text { recycling }\end{array}$ & $93 \% \pm 7$ & $\begin{array}{l}\text { after } \\
\text { internalization }\end{array}$ \\
\hline $15 \mathrm{~min}$ & $84 \% \pm 8$ & $91 \% \pm 3$ & $76 \% \pm 9$ & $88 \% \pm 5$ \\
$2 \mathrm{~h}$ & $87 \% \pm 10$ & $88 \% \pm 8$ & $78 \% \pm 1$ & $87 \% \pm 2$ \\
$6 \mathrm{~h}$ & $87 \% \pm 8$ & $91 \% \pm 3$ & $81 \% \pm 2$ & $79 \% \pm 1$ \\
$20 \mathrm{~h}$ & $90 \% \pm 5$ & $81 \% \pm 21$ & $82 \% \pm 14$ \\
\hline
\end{tabular}

IR-CHO cells were incubated in the presence or absence of native or encapsulated insulin $\left(10^{-7} \mathrm{~mol} / \mathrm{l}\right)$ for $15 \mathrm{~min}, 2,6$ or $20 \mathrm{~h}$ and then acid-washed. ${ }^{125}$ I-labelled insulin binding was performed as described in Materials and methods immediately or after allowing for the recycling of receptors. Results expressed as percentage of binding to control cells taken as $100 \%$. All assays were done in duplicate and points are means $\pm S D$ of three separate experiments. No significant differences were found according to Student's $t$-test 


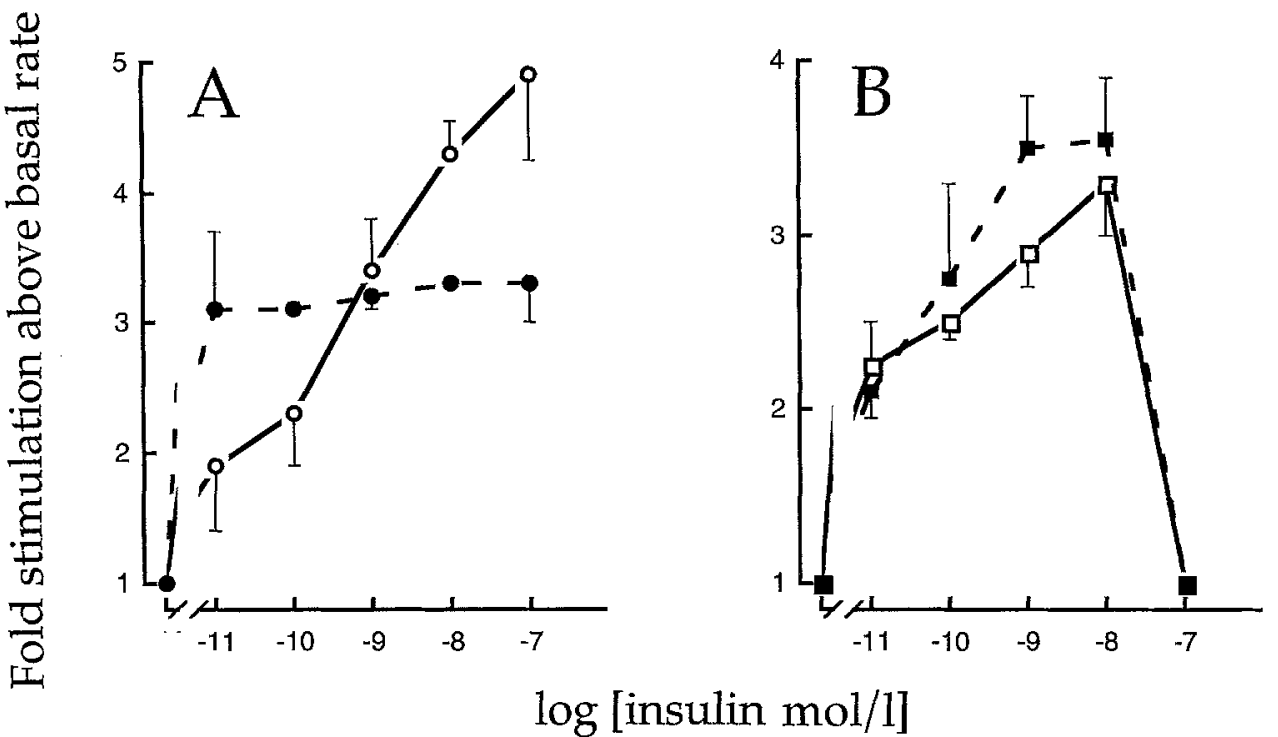

Fig. 2A, B. Effects of chloroquine on native $(\mathbf{A})$ and encapsulated (B) insulin-stimulated glycogenesis. Experimental procedure as described in Figure 1A in absence (open symbols) or presence (closed symbols) of chloroquine $(0.2 \mathrm{mmol} / \mathrm{l})$. Results are expressed as factors of stimulation compared to non-treated cells. Each point was determined in triplicate and represents the mean $\pm \mathrm{SD}$ of two experiments on two different cultures

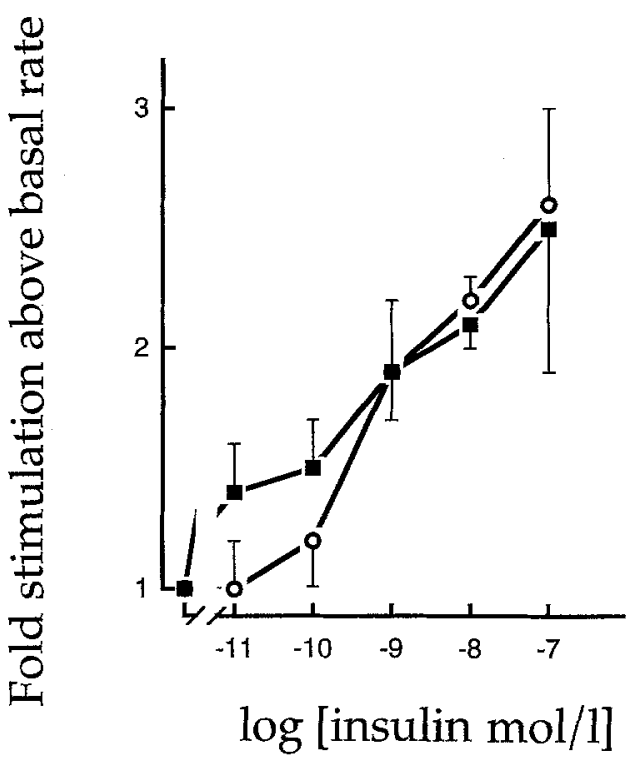

Fig.3. Effects of native and encapsulated insulin on glycogen synthesis after dissociation of membrane-bound ligand. IR$\mathrm{CHO}$ cells were pre-incubated for $1 \mathrm{~h}$ with native (O) or encapsulated ( $\boldsymbol{D}$ ) insulin and then acid-washed as described in Materials and methods. Incubation was then continued for $3 \mathrm{~h}$. Incorporation of $\left[{ }^{14} \mathrm{C}\right]$ glucose was measured as described in Figure 1. All points were determined in triplicate and represent the means \pm SD of three experiments on three different cultures. No statistical differences between native and encapsulated insulin were found according to unpaired Student's $t$ test

In order to examine this possibility, we used chloroquine which is an inhibitor of endosomal degradation and leads to accumulation of internalized insulin in intracellular vesicles. In the presence of chloroquine, the maximal efficacy of native insulin was diminished by a factor of 1.5. However, encapsulated insulin elicited the same dose-response profile either in the absence or in the presence of chloroquine (Fig.2). The fact that chloroquine decreased maxi- mal native insulin stimulation of glycogen synthesis without altering the effect of encapsulated insulin indicates that a decrease of intracellular degradation may participate in the observed decrease of encapsulated insulin efficacy at high doses.

Glycogen synthesis after acid-induced dissociation of the membrane ligand. Synthesis of glycogen was also examined after removal of bound ligand after $1 \mathrm{~h}$ of incubation by cell treatment at $\mathrm{pH} 6$ (Fig.3). The maximal stimulation by native insulin was decreased by about $53 \%$, whereas the encapsulated insulin dose-response curve had a normal shape and was superimposable on that for native insulin. The desensitization induced by encapsulated insulin is thus fully reversible upon washing away the hormone. The appearance of bell-shaped dose-response curves for encapsulated insulin may thus be related to persistent occupation of the receptor.

Assay of insulin binding activity after incubation with cultured cells. These results led us to investigate the rate of disappearance of active insulin from the culture medium by IR-CHO cells at high ligand concentrations. Since common methods for measurement of insulin integrity (such as precipitation with trichloroacetic acid or radioimmunoassay) are not applicable in the presence of the polymer, we were obliged to use a binding assay, in which samples of the incubation medium were used as competitors. Results of these experiments are shown in Figure 4. In each case, disappearance of effective native or encapsulated insulin was rapid, with more than $60 \%$ of the hormone being lost after $5 \mathrm{~min}$. Withdrawal was more efficient at the low concentration of $10^{-8} \mathrm{~mol} / \mathrm{l}$ for both types of insulin. Medium containing empty nanocapsules had no effect at all times. The most striking result was that native insulin clearly disappeared much 


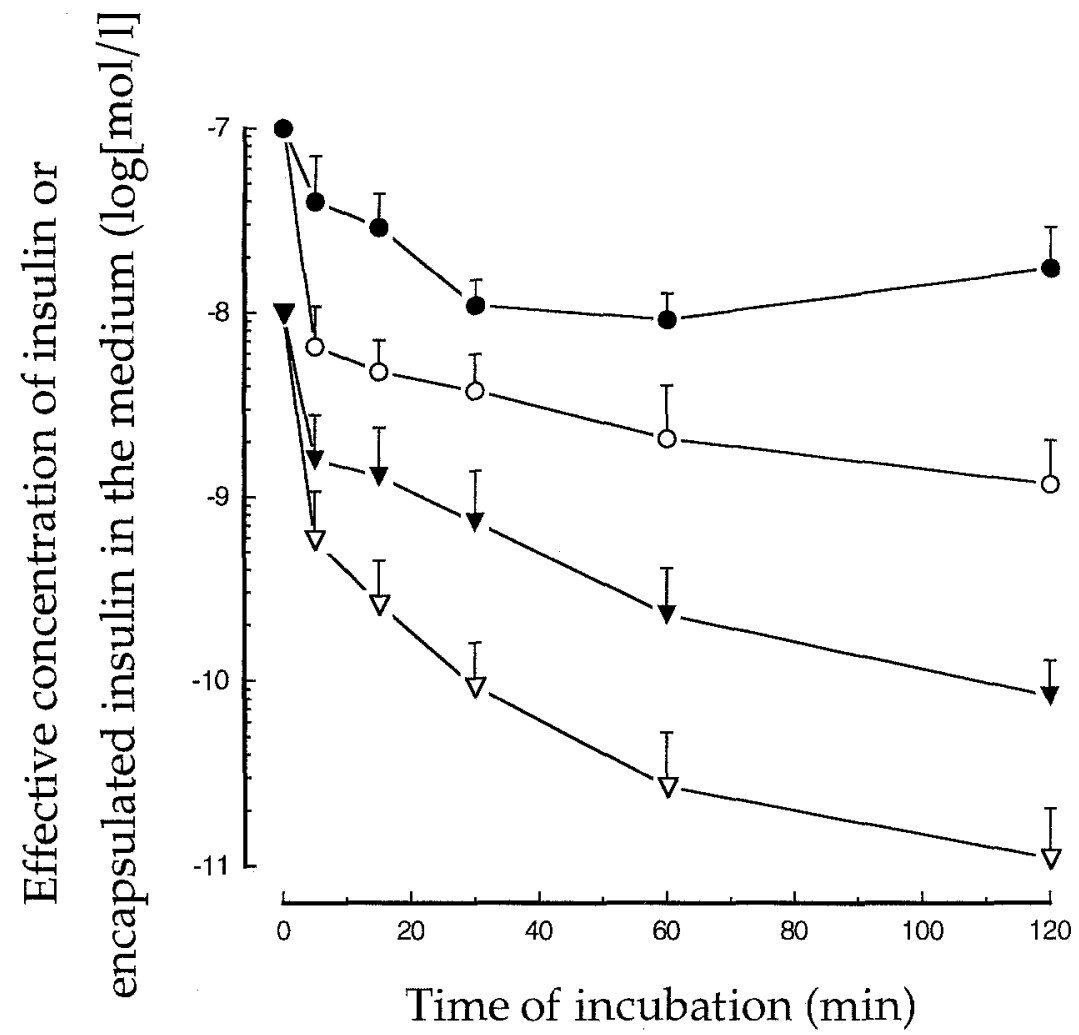

Fig. 4. Determination of withdrawal of native or encapsulated insulin in IR-CHO cells medium. Native (open symbols) or encapsulated (closed symbols) insulin at $10^{-7} \mathrm{~mol} / 1(\mathrm{O}, \mathrm{O})$ and $10^{-8} \mathrm{~mol} / \mathrm{l}(\nabla, \nabla)$ was incubated for up to $2 \mathrm{~h}$ with IR-CHO cells in culture dishes. An aliquot of the incubation buffer was taken at the indicated times, and was tested for its ability to displace ${ }^{125}$ I-insulin binding to solubilized insulin receptors as detailed in Materials and methods. Results are expressed as effective concentration of insulin in the medium, and were determined from standard competition curves performed in parallel. All points were determined in duplicate and represent the mean \pm SD of four different experiments. Differences between native and encapsulated insulin were significant $(P<0.05$ or better $)$ for both concentrations at all times tested (according to unpaired Student's $t$-test) faster than encapsulated insulin from the incubation buffer at the two concentrations used, $10^{-8} \mathrm{~mol} / 1$ and $10^{-7} \mathrm{~mol} / \mathrm{l}$. This was already evident at early time points, and the difference between effective concentrations of native and encapsulated insulin remained roughly constant throughout the experiment (5-8 times more intact encapsulated insulin than native hormone). At $10^{-7} \mathrm{~mol} / \mathrm{l}$, encapsulated insulin appeared to stabilize on a plateau after a 30 min incubation period. Together with our previous results [10], the present data suggest that native and encapsulated insulin are identically internalized, but differ in their rate of degradation. Intact encapsulated insulin may then accumulate intracellularly or be recycled back into the extracellular medium or both. This would lead to persistent occupation and stimulation of receptors.

\section{Discussion}

It has previously been shown that encapsulated insulin normalizes fasting glycaemia for a long period after oral administration to streptozotocin-induced diabetic rats [9]. We have also recently examined the interactions between encapsulated insulin and the insulin receptor in vitro and clearly demonstrated that this form of insulin is able to bind to insulin receptors and to stimulate receptor autophosphorylation in a doseand time-dependent manner similar to that of native insulin. After binding, encapsulated insulin is inter- nalized but differs from native insulin by its slow degradation inside the cell [10]. In view of these results, it has been postulated that encapsulated insulin is an original, long-lasting form of insulin which could generate specific biological effects at the cellular level.

In this report, we have compared the effects of native and encapsulated insulin on glycogen and DNA synthesis in CHO cells transfected with the human insulin receptor gene. The results show that in the $10^{-1.1}$ $-10^{-9} \mathrm{~mol} / \mathrm{l}$ range, encapsulated insulin stimulated glycogen and DNA synthesis in a similar manner to that of native insulin. At higher concentrations, responses to encapsulated insulin decreased, generating an atypical bell-shaped dose-response curve. Although such biphasic dose-response curves are not common, they have been described for other signalling systems, even for insulin-sensitive systems [16, 17]. Mechanisms underlying the generation of these biphasic responses are poorly understood. In the present study, the biphasic dose-response curve does not result from toxic effects of the polymer. Nor is it apparently due to the overexpression of insulin receptors in the cells used here since similar bell-shaped dose-response curves were found on rat adipocytes, expressing normal amounts of insulin receptors, for the stimulation of glucose transport by encapsulated insulin (data not shown).

The observed loss of responsiveness to higher doses of encapsulated insulin might be explained by the phenomenon of cellular desensitization. Different and possible combinations of mechanisms of desensi- 
tization of insulin receptors have been described; these involve either intracellular routing (internalization and down-regulation), alterations of insulinreceptor functions, or alterations in intracellular pathways $[18,19]$.

We have previously shown that the in vitro properties of encapsulated insulin are identical to those of the native hormone with regard to receptor binding and kinase activation [10]. Labelled encapsulated insulin (at $\approx 10^{-10} \mathrm{~mol} / \mathrm{l}$ ) was internalized in IR-CHO cells to a similar extent as for the native hormone. The main difference was that encapsulated insulin remained essentially intact after $3 \mathrm{~h}$ [10]. In the present study, we investigated whether the observed anomalous dose-response curves for encapsulated insulin could be related to its less pronounced intracellular degradation. First, the accumulation of intact insulin inside cells may alter internalization, recycling and down-regulation of the receptors. Assay of cell-surface receptors after incubation with $10^{-7} \mathrm{~mol} / \mathrm{l}$ insulin or encapsulated insulin showed no differences for up to $20 \mathrm{~h}$ (Table 1), indicating that internalization and down-regulation were not altered. Chloroquine, an inhibitor of endosomal degradation, decreased the effect of native insulin without affecting the dose-response characteristics of encapsulated insulin. In addition, decreasing the occupation of cell-surface receptors by acid-washing of the cells restored glycogen synthesis at high concentrations of encapsulated insulin to levels similar to those obtained with the native hormone. These results show that the observed desensitization produced by encapsulated insulin is probably not related to alterations in intracellular routing of the receptor, but is apparently due to the persistence of non-degraded insulin when it is encapsulated. To further investigate this hypothesis, we studied the disappearance of both forms of insulin from the incubation medium. In this experiment, we measured the overall disappearance of available insulin, which resulted from different mechanisms: cell-surface degradation, internalization and intracellular degradation and non-specific binding. At the two concentrations used, $10^{-8} \mathrm{~mol} / 1$ and $10^{-7} \mathrm{~mol} / 1$, results clearly showed that encapsulated insulin disappeared far less than native insulin from the incubation buffer. Again, this observation was not due to use of transfected cells, since very similar results were obtained with wild-type CHO cells, which have been shown to actively metabolize insulin [20] (data not shown). These results lend further support to the idea that, while it is biologically active, encapsulated insulin is protected from proteolytic degradation by the polymer. This has already been shown by its protection from proteolysis in vitro [6], and HPLC analysis of encapsulated ${ }^{125}$ I-insulin after internalization in IR-CHO cells [10].

It appears that the observed atypical bell-shaped dose-response curves of glycogen synthesis stimula- tion by encapsulated insulin do not involve alterations in intracellular routing of insulin receptors in the present study. The persistence of extracellular and possibly intracellular hormone seems to be of prime importance in the decreased responsiveness induced by encapsulated insulin. The subcellular localization and intracellular fate of non-degraded encapsulated insulin remain largely unknown, and we cannot exclude that the modified hormone is recycled with or without its receptor. This could explain the apparent plateau for the effective concentration of encapsulated insulin at $10^{-7} \mathrm{~mol} / 1$ after $30 \mathrm{~min}$, and could also be involved in the desensitization process. Nevertheless, the fact that responsiveness of encapsulated insulin at $10^{-8} \mathrm{~mol} / \mathrm{l}$ is already decreased, while its concentration in the medium after $2 \mathrm{~h}$ remains less than that of normally active insulin $10^{-7} \mathrm{~mol} / \mathrm{l}$ (Fig.4), suggests that intracellular accumulation of undegraded encapsulated insulin is important for the desensitization phenomenon. Whatever the case, persistent occupation of insulin receptors by intact encapsulated insulin may activate regulatory mechanisms leading to the observed desensitization of the hormone biological effects.

How are the present findings related to the longlasting effect of encapsulated insulin on glycaemia observed in diabetic rats? It has previously been shown that the degradation of the polymer is not a prerequisite for the action of insulin, since encapsulated insulin binds directly to insulin receptors, and that internalized encapsulated insulin is slowly degraded [10]. These results suggested that the polymer does not hinder binding to its receptor and that it protects insulin from intracellular proteolytic degradation. In the present report, we have shown that encapsulated insulin at physiological concentrations stimulates glycogen and thymidine synthesis in an identical way to native insulin. The desensitization observed for higher concentrations of encapsulated insulin is most probably related to its lower degradation, which yields a further argument for the protection of insulin by the polymer in cells. It has been shown that the duration of the effect of encapsulated insulin in vivo depends more on the insulin/polymer ratio rather than solely on the amount of insulin $[9,21]$. The degradation of the polymer could modulate insulin activity by modifying the concentration of insulin available for degradation. Thus, the long lasting action of encapsulated insulin in vivo could be explained by the slow degradation of insulin, which in turn depends on the degradation of the polymer. Also, the cellular desensitization induced by higher concentrations of encapsulated insulin may explain why its normoglycaemic effect in the rat is delayed by about 2 days after oral administration [9].

In conclusion, we have shown that encapsulated insulin is a long-lasting form of insulin, the biological 
action of which at the cellular level is similar to that of native insulin in the physiological $10^{-11}-10^{-9} \mathrm{~mol} /$ 1 concentration range, in cells transfected with insulin receptor cDNA. At higher concentrations, cellular desensitization occurs in response to intracellular and extracellular accumulation of insulin. The desensitization is already evident for relatively short periods of stimulation ( $4 \mathrm{~h}$ for glycogen synthesis), and is apparently not related to receptor internalization and down-regulation. Persistence of intact encapsulated insulin inside and outside the cell may provoke a blockade in signal transmission and thus be responsible for the observed cellular desensitization.

Acknowledgements. We thank Dr. E. Clauser (INSERM U. 36, Paris, France) for the gift of IR-CHO cells and helpful suggestions, and Dr. J. Capeau (INSERM U. 402, Paris, France) for fruitful discussions. We thank Dr. K. Langley for revising the manuscript. This work was supported by a grant from the association "Aide aux Jeunes Diabétiques" to M. R.

\section{References}

1. Réach G (1991) Immunoprotected islets of Langerhans as a bioartificial pancreas. In: Pickup JC (ed) Frontiers in pharmacology and therapeutics. Biotechnology of insulin therapy. Blackwell Scientific Publications, Oxford, pp 75-96

2. Sullivan SJ, Maki T, Borland KM et al. (1991) Biohybrid artificial pancreas: long-term implantation studies in diabetic, pancreatectomized dogs. Science 252: 718-721

3. Lassman-Vague V (1991) The intranasal route for insulin administration. In: Pickup JC (ed) Frontiers in pharmacology and therapeutics. Biotechnology of insulin therapy. Blackwell Scientific Publications, Oxford, pp 113-125

4. Eppstein DA, Longnecker JP (1988) Alternative delivery systems for peptides and proteins as drugs. Crit Rev Ther Drug Carrier Syst 5: 99-139

5. Aprahamian M, Michel C, Humbert W, Devissaguet JP, Damgé C (1987) Transmucosal passage of polyalkylcyanoacrylate nanocapsules as a new drug carrier in the small intestine. Biol Cell 61: 69-76

6. Damgé $C$, Michel $C$, Aprahamian M, Couvreur P, Devissaguet JP (1990) Nanocapsules as carriers for oral peptide delivery. J Controlled Release 13: 233-239

7. Kante B, Couvreur P, Dubois-Krack G et al. (1982) Toxicity of polyalkylcyanoacrylate nanoparticles. I. Free nanoparticles. J Pharm Sci 71: 786-790
8. Lenaerts V, Couvreur P, Christiaens-Leyh D, Joiris E, Roland M, Rollman B, Speiser P (1984) Degradation of poly(isobutylcyanoacrylate) nanoparticles. Biomaterials 5: 65-68

9. Damgé C, Michel C, Aprahamian M, Couvreur P (1988) New approach for oral administration of insulin with polyalkylcyanoacrylate nanocapsules as drug carrier. Diabetes 37: 246-251

10. Roques M, Damgé C, Michel C, Staedel C, Crémel G, Hubert $P$ (1992) Encapsulation of insulin for oral administration preserves the interactions of the hormone with its receptor in vitro. Diabetes 41: 451-456

11. Crestfield AM, Moore S, Stein WH (1963) The preparation and enzymatic hydrolysis of reduced and S-carboxymethylated proteins. J Cell Biol 238: 622-637

12. Ellis L, Clauser E, Morgan DO, Edery M, Roth RA, Rutter WJ (1986) Replacement of insulin receptor tyrosine residues 1162 and 1163 compromises insulin-stimulated kinase activity and uptake of 2-deoxyglucose. Cell 45: 721-732

13. Leconte I, Auzan C, Debant A, Rossi B, Clauser, E (1992) $\mathrm{N}$-linked oligosaccharide chains of the insulin receptorbeta subunit are essential for transmembrane signalling. $J$ Biol Chem 267: 17415-17423

14. Le Marchand-Brustel Y, Ballotti R, Van Obberghen E (1988) Insulin receptor kinase activity in states with altered insulin action. In: Kahn CR, Harrison LC (eds) Insulin receptors, part A. Alan R. Liss, New York, pp 163-179

15. Vogt B, Carrascosa JM, Ermel B, Ullrich A, Häring HU (1991) The two isotypes of the human insulin receptor (HIR-A and HIR-B) follow different internalization kinetics. Biochem Biophys Res Comm 177: 1013-1018

16. Robertson ADJ (1987) Biphasic responses, quantal signals and cellular behavior. $J$ Theor Biol 125: 41-60

17. Seals JR, Jarett L (1980) Activation of pyruvate dehydrogenase by direct addition of insulin to an isolated plasma membrane/mitochondria mixture. Proc Natl Acad Sci USA 77: 77-81

18. Heaton JH, Gelehrter TD (1981) Desensitization of hepatoma cells to insulin action. Evidence for a post-receptor mechanism. J Biol Chem 256: 12257-12262

19. Lohse MJ (1993) Molecular mechanisms of membrane receptor desensitization. Biochim Biophys Acta 1179: 171188

20. Reynet C, Caron M, Magré J et al. (1990) Mutation of tyrosine residues 1162 and 1163 of the insulin receptor affects hormone and receptor internalization. Molec Endocrinol 4: 304-311

21. Michel C, Aprahamian M, Defontaine L, Couvreur P, Damgé C (1991) The effect of site of administration in the gastrointestinal tract on the absorption of insulin from nanocapsules in diabetic rats. J Pharm Pharmacol 43: 1-5 